ENTREPRENEURSHIP AND SUSTAINABILITY ISSUES

ISSN 2345-0282 (online) http://jssidoi.org/jesi/ 2020 Volume 8 Number 1 (September)

http://doi.org/10.9770/jesi.2020.8.1(69)

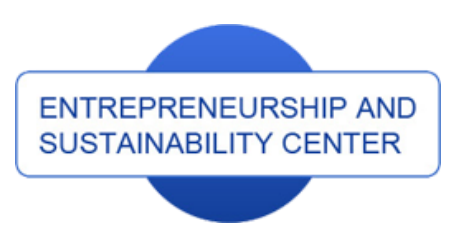

Publisher

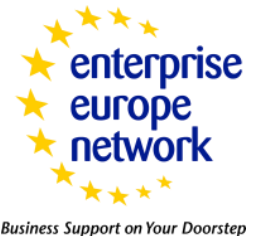

CASPA

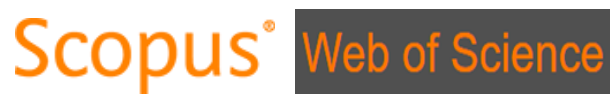

http://jssidoi.org/esc/home

Business Support on Your Doorstep

\title{
thes
}

\section{THE INFLUENCE OF MACROECONOMIC VARIABLES, PROCESSING INDUSTRY, AND EDUCATION SERVICES ON ECONOMIC GROWTH IN INDONESIA*}

\author{
Nano Prawoto ${ }^{1}$, Agus Tri Basuki ${ }^{2}$ \\ 1,2 Economics and Business Faculty Universitas Muhammadiyah Yogyakarta, Indonesia \\ E-mails: ${ }^{1}$ nanopra@umy.ac.id ; ${ }^{2}$ agustribasuki@yahoo.com
}

Received 10 October 2019; accepted 30 June 2020; published 30 September 2020.

\begin{abstract}
This study aims to look at the effect of Human Development Index (HDI), consumption, investment, and imports on economic growth in Indonesia and especially in the Province of Yogyakarta from 2010 to 2018. The research model used was panel data. The findings showed that HDI had a negative influence on economic growth. This happens because the education fee and health costs are expensive in Indonesia. Other findings implied that the number of imported goods did not have an influence on economic growth in the Special Province of Yogyakarta. Therefore, this issue needs to be studied seriously since it will have an impact on unemployment.
\end{abstract}

Keywords: Human Development Index; consumption; investment; imports; economic growth

Reference to this paper should be made as follows: Prawoto, N., Basuki, A.T. 2020. Tne Influence of macroeconomic variables, processing industry, and education services on economic growth in Indonesia. Entrepreneurship and Sustainability Issues, 8(1), 1029-1040. http://doi.org/10.9770/jesi.2020.8.1(69)

JEL Classifications: E27, E44

\section{Introduction}

Basically, regional development cannot be separated from national development. One of Indonesia's national development goals is to create economic growth and equitable distributions, including the distribution of income among regions. To achieve the above target is not easy because in general, the economic development of an area is closely related to the economic potential and its characteristics (Todaro \& Smith, 2003).

According to (Todaro \& Smith, 2003), Gross Domestic Regional Product (GDRP) is the total value of all final output produced by an economy at the regional level (both that is done by local residents and residents of other regions who live in the area). The amount of production or output of goods and services produced by the region/province/district/city is referred to as the Gross Regional Domestic Product. GDRP is valued in monetary

\footnotetext{
* LP3M Universitas Muhmamadiyah Yogyakarta, Indonesia supported this research.
} 


\section{ENTREPRENEURSHIP AND SUSTAINABILITY ISSUES}

ISSN 2345-0282 (online) http://jssidoi.org/jesi/ 2020 Volume 8 Number 1 (September) http://doi.org/10.9770/jesi.2020.8.1(69)

units (Rupiah) and detailed based on various economic activities that build the economy of the area, such as agriculture, mining, manufacturing industry, trade, and so on.

Based on the data in Table 1, it can be seen from 2018 that the economic growth of the Special Region of Yogyakarta grew by an average of between 4.95 percent and 6.2 percent. From the 17 existing sectors, the sectors that have the largest contribution are; Processing Industry (12.74\%), Information and Communication (11.1\%), Construction (10.19\%), Accommodation and Food and Beverages (9.57\%) and Education Services (8.76\%). While the sectors that have the lowest contribution are: Water Supply, Waste Management, Waste and Recycling $(0.1 \%)$, Electricity and Gas Procurement (0.16\%), Mining and Quarrying (0.55\%), Company Services $(1,17 \%)$ and Health Services and Social Activities (2.65\%) (see Table 1).

Table 1. PDRB Contribution of Yogyakarta (Million Rupiah), Year $2018(2010=100)$

\begin{tabular}{|c|c|c|}
\hline Sectors & 2018 & $\begin{array}{c}\text { Average } \\
\text { contribution from } \\
2014-2018 \\
\end{array}$ \\
\hline A. Agriculture, Forestry, and Fisheries & 8.101 .333 & 8.26 \\
\hline B. Mining and Excavation & 541.184 & 0.55 \\
\hline C. $\quad$ Processing Industry & 12.487 .005 & 12.74 \\
\hline D. $\quad$ Electricity and Gas Procurement & 156.707 & 0.16 \\
\hline E. Water Supply, Waste Management, Waste and Recycling & 94.923 & 0.10 \\
\hline F. Construction & 9.987 .059 & 10.19 \\
\hline G. Wholesale and Retail Trade; Car and Motorcycle Repair & 8.219 .289 & 8.38 \\
\hline H. $\quad$ Transportation and Warehouse & 5.304 .844 & 5.41 \\
\hline I. Accommodation and Food and Beverages & 9.383 .603 & 9.57 \\
\hline J. Information and Communication & 10.884 .533 & 11.10 \\
\hline K. $\quad$ Financial Services and Insurance & $3,506,588$ & 3.58 \\
\hline L. Real Estate & $7,079,839$ & 7.22 \\
\hline M. Company Services & $1,146,812$ & 1.17 \\
\hline $\begin{array}{l}\text { N. Government Administration, Defense, and Mandatory Social } \\
\text { Security }\end{array}$ & $7,239,152$ & 7.38 \\
\hline O. Education Services & $8,583,074$ & 8.76 \\
\hline P. $\quad$ Health Services and Social Activities & 2.593 .233 & 2.65 \\
\hline Q. Other Services & 2.717 .386 & 2.77 \\
\hline Gross Regional Domestic Product & 98.026 .564 & 100.00 \\
\hline Economic Growth & 6.20 & \\
\hline
\end{tabular}

Source: Central Statistics Agency (Badan Pusat Statistik - BPS) Yogyakarta

The following are several studies conducted to find out about what factors can influence the economic growth of a region: Research on the Effect of the Human Development Index on economic growth was carried out by Ranis, G., at al. (2000). The results of the study concluded that economic and social policies prioritize prioritizing getting the right economic fundamentals as a prerequisite needed for economic growth, while Enhancing Human Development (HD) must wait for economic growth (EG). His findings do not deny the importance of economic reform, but support the focus on HD must be included from the beginning of each reform program. Restoring the economy itself will not be resolved unless it is preceded or approved with an increase in HD. While research Suri, T., at al. (2011) signifies that HD is not only an EG product, but also an important input for EG. This paper develops a new empirical strategy to increase the power of two directions connecting HD and EG. Based on the existing growth literature, they explored the drainer of the positive growth trajectory that goes from HD to EG and found that HD plays an important role in explaining economic growth (EG). Azeem Qureshi's (2009) concludes that higher public spending on human development increases human development indicators and increases (+) economic growth. Akanbi Research, at. All (2014) concludes that the human development index in Negeria inhibits (-) economic growth. 


\section{ENTREPRENEURSHIP AND SUSTAINABILITY ISSUES}

ISSN 2345-0282 (online) http://jssidoi.org/jesi/

2020 Volume 8 Number 1 (September)

http://doi.org/10.9770/jesi.2020.8.1(69)

Research conducted by Haraguchi, Cheng \& Smeets (2017) refutes the statement of the development of manufacturing in developing countries and increases the importance of manufacturing for economic development. This study shows that there is no evidence (?) That supports this argument. Su \& Yao's study (2017) concludes that its empirical findings indicate that the manufacturing sector is still the main engine of growth (+) for middleincome countries. The research of Behun, Gavurova, Tkacova \& Kotaskova (2018) concluded that the manufacturing industry is a sector with significant cycle behavior. In most countries, production and sales in the manufacturing industry behave as concurrent indicators, changes in production and sales are immediately reflected in the growth or decline in GDP.

Research by Feriyantoa \& El Aiyubbic (2019), Rafiy, Adam, Bachmid \& Saenong (2018) and Ramli \& Andriani (2013) concluded that consumption expenditure has a positive (+) effect on economic growth. Aslam's research (2017) concludes that consumption expenditure is a very important element to promote economic growth, which is confirmed by sufficient empirical studies in various countries. Alas, in Sri Lanka there is no evidence of a relationship (?) Between consumption spending and economic growth.

Kartikasari Research (2017) concluded that there is a negative relationship (-) between imports and economic growth. Research by Bakari \& Mabrouki (2017), Hussain \& Saaed (2015) and Kim, Lim \& Park (2007) concluded that imports have a significant positive (+) effect on productivity growth. Most of the research results still use the growth of gross domestic product rather than productivity growth as a measure of economic growth. Ali, Ali \& Dalmar (2018) conclude that imports in the short term have no (?) Effect on economic growth.

Based on the results of these studies can be used as a reference to see whether the economic growth of the special region of Yogyakarta is also influenced by the factors mentioned above. Does the index of human development, household consumption and government consumption, education services, processing industry and imports affect the economic growth of the special region of Yogyakarta.

\section{Review on Previous Studies}

Economic growth is a process of changing a country's economic conditions on an ongoing basis towards better conditions for a certain period. Economic growth can also be interpreted as a process of increasing the production capacity of an economy that is realized in the form of an increase in national income. The existence of economic growth is an indication of the success of economic development in people's lives. Economic growth shows the growth of production of goods and services in an economic region within a certain time interval. The higher the rate of economic growth, the faster the process of increasing regional output so that the prospects for regional development are better. By knowing the sources of economic growth, the priority development sectors can be determined. According to Todaro and Smith (2003) there are three main factors or components that influence economic growth, namely capital accumulation, growth in population, and technological progress.

Based on the above background economic growth is influenced by the human development index, public consumption and government consumption, the processing industry and the import of goods. The composite Human Development Index (HDI) in-tegrates three basic dimensions of human develop-ment. Life expectancy at birth reflects the ability to lead a long and healthy life. Mean years of schooling and expected years of schooling reflect the ability to acquire knowledge. And gross national income per capita reflects the ability to achieve a decent stan-dard of livin (Jahan, S. 2017). While the definition of the Human Development Index (HDI) in Indonesia measures the achievements of human development based on a number of basic components of quality of life. As a measure of quality of life, HDI is built through a basic three-dimensional approach. These dimensions include long and healthy life; knowledge, and a decent life. These three dimensions have a very broad understanding because they are related to many factors. To measure the dimensions of health, life expectancy at birth is used. Next to measure the dimensions of knowledge used a combination of literacy rate indicators and 


\section{ENTREPRENEURSHIP AND SUSTAINABILITY ISSUES}

ISSN 2345-0282 (online) http://jssidoi.org/jesi/

2020 Volume 8 Number 1 (September)

http://doi.org/10.9770/jesi.2020.8.1(69)

average length of school. As for measuring the dimensions of decent living, an indicator of people's purchasing power is used for a number of basic needs as seen from the average amount of expenditure per capita as an income approach that represents development achievements for decent living (Statistik, B. P. 2017).

The effect of HDI on Imports was carried out by Elistia \& Syahzuni (2018), Daniela \& Oana (2015) and Shome \& Tondon (2010) concluded that there is a relationship and effect of the value of the Human Development Index on Gross Domestic Product (GDP).Research on the Effect of the Human Development Index on economic growth was carried out by Ranis, G., at al. (2000). His findings do not deny the importance of economic reform, but support the focus on HD must be included from the beginning of each reform program. While research Suri, T., at al. (2011) signifies that HD is not only an EG product, but also an important input for EG. Azeem Qureshi's research (2009) concludes that higher public spending on human development increases human development indicators and increases (+) economic growth. Research by Akanbi, at. all (2014) concluded that the human development index in Negeria could hamper (-) economic growth.

Research conducted by Haraguchi, Cheng \& Smeets (2017) refutes the statement of the development of manufacturing in developing countries and increases the importance of manufacturing for economic development. This study shows that there is no evidence (?) That supports this argument. Su \& Yao's (2017) study concludes that their empirical findings indicate that the manufacturing sector is still the main engine driving driver (+) for middle-income countries. The research of Behun, Gavurova, Tkacova \& Kotaskova (2018) concluded that the manufacturing industry is a sector with significant cycle behavior. In most countries, production and sales in the manufacturing industry behave as concurrent indicators, changes in production and sales are reflected in GDP growth or decline.

Research by Rafiy, Adam, Bachmid \& Saenong (2018) and Ramli \& Andriani (2013) concluded that consumption expenditure has a positive (+) effect on economic growth. Aslam's research (2017) concludes that consumption expenditure is a very important element to drive economic growth, which is confirmed by adequate empirical studies in various countries. The case of Sri Lanka is no evidence of a relationship (?) Between consumption expenditure and economic growth. Research conducted by Abdul Karim, Abdul Karim \& Ahmad (2010) discusses the dynamic relationship between economic growth, fixed investment, and household consumption in Malaysia using a structural vector error correction (SVECM) model approach. Empirical results reveal that household consumption and fixed investment only significantly affect output growth in the short run. This finding tends to support an alternative view of the growth hypothesis, namely growth triggered by fixed investment, and growth driven by household consumption in the short run.

Research conducted by Bakari \& Mabrouki (2016) aims to explore the relationship between exports, imports, and economic growth in Turkey. Annual data is taken for the period between 1960 and 2015. The model used is the Vector Auto Regression Model and the Granger-Causality test. The results of his research show strong evidence of two-way causality from imports to economic growth and from exports to economic growth. Kartikasari Research (2017) concludes that there is a negative relationship (-) between imports and economic growth. Kim, Lim \& Park's (2007) study concluded that imports had a significant positive (+) effect on productivity growth. Most of the research results still use the growth of gross domestic product rather than productivity growth as a measure of economic growth. Ali, Ali \& Dalmar (2018) conclude that imports in the short term have no (?) Effect on economic growth.

Research conducted by Iskandar, (2017) aims to determine the index of human development on economic growth through the granting of special autonomy. The method used panel data regression. The results showed that moderation between the human development index through special autonomy funds had a significant negative effect on economic growth. 
Based on the previous study above, the results of the research can be used as a basis for analyzing the influence of the human development index, consumption, investment and imports on economic growth in the Special Province of Yogyakarta and at the same time to see which sectors have the dominant influence on economic growth.

This study discusses the factors that influence economic growth in the Special Region of Yogyakarta, so that this study cannot represent the case of Indonesia, due to the limited data that researchers have. Because HDI has the role of driving economic growth, the role of government spending on health and education is very important to be considered in the analysis, but researchers only use government spending through total government consumption in this study.

\section{Research Methodology}

Based on the background and objectives of the study, the factors that determine economic growth are as follows: GDRP: $f$ (HDI, CRT, CPEM, INDPENG, JSPEND, IMPORT). The model used in this study is the dynamic panel data model (Panel PAM). Model development as follows:

Regression models that show the relationship between the dependent variable and the independent variables distributed based on a certain time period are commonly called Distributed Lag Models (Gujarati, 2003).

Distributed Lag Models or Infinite Lag Models, can be written as follows

$$
Y_{t}=\alpha+\beta_{0} X_{t}+\beta_{1} X_{t-1}+\beta_{2} X_{t-2}+. \beta_{3} X_{t-3}+\ldots+\varepsilon_{t}
$$

The Adaptive Expectation Model is specified by paying attention to expectations in the future. Although experience in the past can be used as a guide for predictions in the future.

The adaptive expectation model is formulated in the following forms:

$$
Y_{t}=\beta_{0}+\beta_{1} X_{t}^{*}+\varepsilon_{t}
$$

This model illustrates that the value $Y_{t}$ depends or is influenced by the value of $\mathrm{X}$ at the time $\mathrm{t}$ expected in the current period to be produced in the future period (Lains, 2006). Because hopeful $X_{t}^{*}$ variables cannot be directly observed, Cagan and Friedman put forward a hypothesis about how these expectations are formed which are then known as the additive expectation hypothesis:

$$
X_{t}^{*}-X_{t-1}^{*}=\pi\left(X_{t}-X_{t-1}^{*}\right)
$$

Where $\pi$ is the coefficient of Expectation with $0<\pi \leq 1$

The rationalization of the Koyck Model is the Partial Adjustment Model (MPA). The consideration of the flexible accelerator model of economic theory assumes that there is an optimal balance in the long run. Suppose the ( $\left.Y_{t}^{*}\right)$ desired capital association $\left(X_{t}\right)$ with income is:

$$
Y_{t}^{*}=\beta_{0}+\beta_{1} X_{t}+\varepsilon_{t}
$$

and the formulation of the partial adjustment or stock adjustment hypothesis is $Y_{t}-Y_{t-1}=\delta\left(Y_{t}^{*}-Y_{t-1}\right)$ where 0

$<\delta 1$ is called the adjustment coefficient; is the actual change of capital; and $Y_{t}^{*}-Y_{t-1}$ is the desired change in capital. This explanation shows that the capital and investment period $\mathrm{t}$ are:

$Y_{t}=\delta Y_{t}^{*}+(1-\delta) Y_{t-i}$ and $. I_{t}=\delta\left(Y_{t}^{*}-Y_{t-1}\right)$

and substitution of equation (4) to equation (5) obtained by actual capital

$$
\begin{aligned}
& Y_{t}=\delta\left(\beta_{0}+\beta_{1} X_{t}+\varepsilon_{t}\right)+(1-\delta) Y_{t-1} \\
& Y_{t}=\delta \beta_{0}+\delta \beta_{1} X+(1-\delta) Y_{t-i}+\delta \varepsilon_{t}
\end{aligned}
$$


This equation is called the Partial Adjustment Model (MPA). Equation (4) explains the balance of capital demand in the long run and equation (5) explains the balance of short-term capital demand. Estimating equation (5) produces a coefficient on long-term capital by knowing the adjustment coefficient $(\delta)$.

The relationship between HDI, household consumption (CRT), government consumption (CPEM), processing industry (INDPENG), education services (JSPEND) and imports IMPOR towards GRDP is stated as follows:

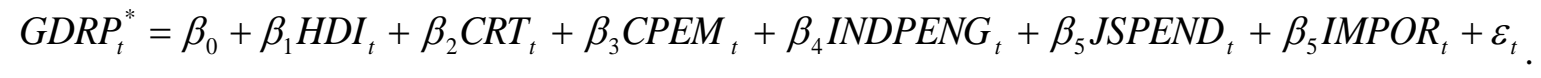

$G D R P_{t}=\delta G D R P_{t}^{*}+(1-\delta) G D R P_{t-i}$

Enter equation (7) into equation (8) so that it is obtained

$$
\begin{aligned}
& \text { GDRP }_{t}=\delta\left(\beta_{0}+\beta_{1} H D I_{t}+\beta_{2} C R T_{t}+\beta_{3} \text { CPEM }_{t}+\beta_{4} \text { INDPENG }_{t}+\beta_{5} \text { JSPEND }_{t}+\right. \\
& \left.\beta_{5} \text { IMPOR }_{t}+\varepsilon_{t}\right)+(1-\delta) G D R P_{t-1} \\
& \text { GDRP }_{t}=\delta \beta_{0}+\delta \beta_{1} H D I_{t}+\delta \beta_{2} C R T_{t}+\delta \beta_{3} \text { CPEM }_{t}+\delta \beta_{4} I_{N D P E N G_{t}+\delta \beta_{5} \text { JSPEND }_{t}+} \\
& \delta \beta_{6} \text { IMPOR }_{t}+\delta \varepsilon_{t}+(1-\delta) G D R P_{t-1}
\end{aligned}
$$

$G D R P_{t}=\alpha_{0}+\alpha_{1} H_{t}+\alpha_{2} C R T_{t}+\alpha_{3}$ CPEM $_{t}+\alpha_{4}$ INDPENG $_{t}+\alpha_{5}$ JSPEND $_{t}+$ $\alpha_{6} I M P O R_{t}+\alpha_{6} G D R P_{t-1}+v_{t}$

Equation (10) which will be used to observe the factors that influence economic growth in the Special Region of Yogyakarta.

The following are the stages of completing the regression analysis with the PAM Model Panel (Figure 1): 


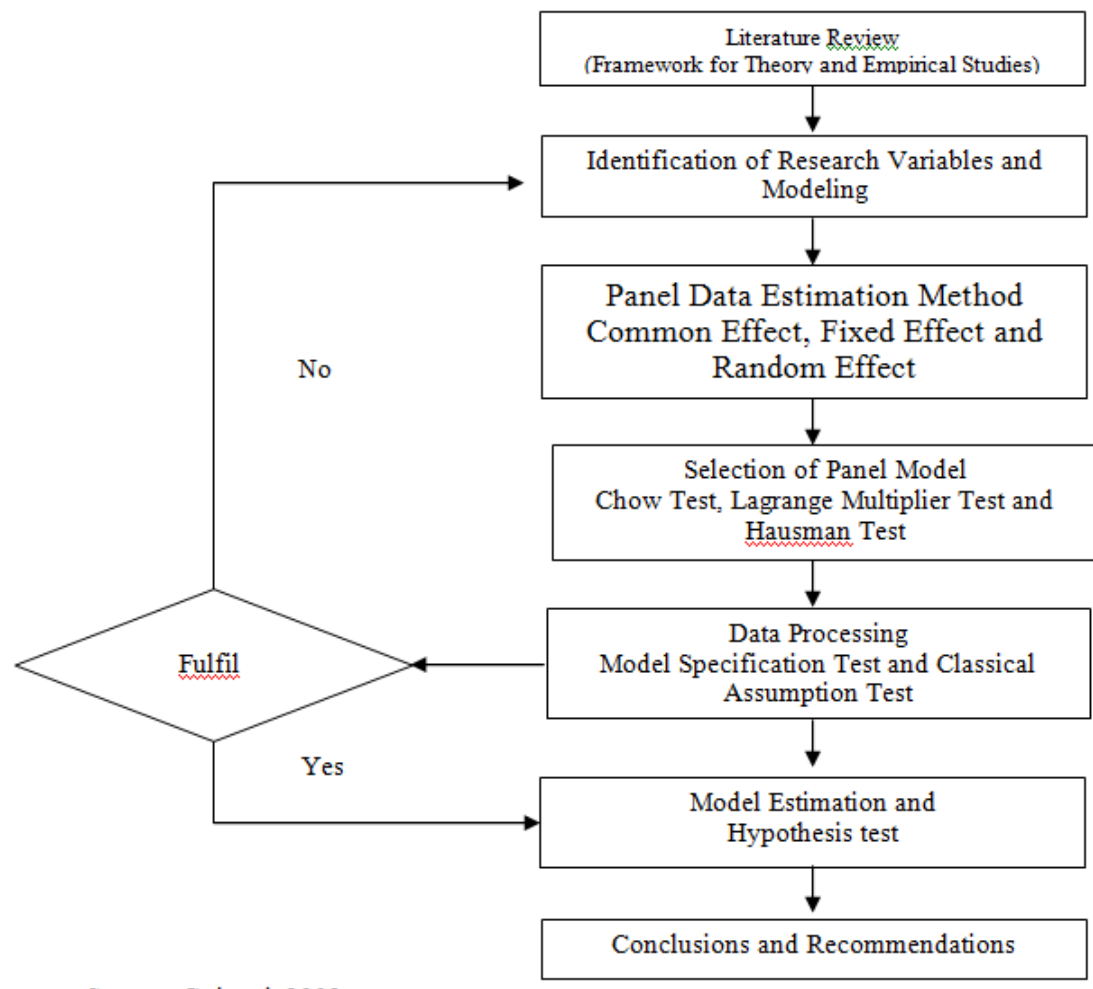

Source: Gujarati, 2003

Figure 1

Steps for PAM Panel Data Research

\section{Data}

In this study, the data used were taken from various Central Statistics Agency (Badan Pusat Statistik - BPS) in Yogyakarta, such as Sleman Regency, Bantul Regency, Kulon Progo Regency, Gunung Kidul Regency, and Yogyakarta City. The time period used is from 2010 to 2018 and for cross data is the City of Yogyakarta, Sleman Regency, Bantul Regency, Kulonprogo Regency and Gunungkidul Regency.

\section{Result and Discussion}

In analyzing panel data 3 regression models will be produced, namely the None Effect model, the Fixed Effect model, and the Random Effect model. The results of the regression to the model are as follows (Table 2). 
Table 2. Data Panel Regression Results

\begin{tabular}{|l|r|r|r|}
\hline \multirow{2}{*}{ Variable } & \multicolumn{2}{c|}{ Coefficient } \\
\cline { 2 - 4 } & \multicolumn{1}{|c|}{ None } & \multicolumn{1}{c|}{ Fixed Effect } & \multicolumn{1}{c|}{ Random effect } \\
\hline HDI & $-0.002843 * * *$ & $-0.004337 * * *$ & $-0.002686 * * *$ \\
\hline LOG(CRT) & $0.175191 * * *$ & $0.233687 * * *$ & $0.200752 * * *$ \\
\hline LOG(CPEM) & $0.119790 * * *$ & $0.137808 * * *$ & $0.096122 * * *$ \\
\hline LOG(INDPENG) & $0.030485 * * *$ & $0.045688 * *$ & 0.017964 \\
\hline LOG(JSPEND) & $0.110999 * * *$ & $0.175596 * * *$ & $0.149276 * * *$ \\
\hline LOG(IMPOR) & 0.022117 & 0.010082 & -0.001641 \\
\hline LOG(PDRB(-1)) & $0.551650 * * *$ & $0.401435 * * *$ & $0.532885 * * *$ \\
\hline C & $0.740903 * * *$ & $1.199868 * * *$ & $1.003165 * * *$ \\
\hline R-squared & 0.999983 & 0.999994 & 0.999950 \\
\hline
\end{tabular}

Source: Author, 2019

Notes:

*** significant at $\alpha 1 \% \quad * *$ significant at $\alpha 5 \% \quad *$ significant at $\alpha 10 \%$

Based on the Chow and Hausman test, the results are consistent and the model meets classical assumptions. It implies that the fixed effect model is more appropriate to be used in this model. The hallmark of the panel adjustment model is that the lag value for GRDP must be significant. The probability for LOG (GRDP (-1)) in Model 1 is smaller than 0.05 , and the magnitude of the coefficient is 0.5716 or $(1-0.4284)$. The meaning of the adjustment coefficient is the expected economic growth with actual economic growth that can be adjusted by 57.16 percent in one period.

Based on Table 3, HDI has a negative influence on economic growth both in the short and long term. The HDI component consists of longevity and healthy life as measured by life expectancy at birth, knowledge calculated from school expectations and an average length of schooling, and a decent standard of living calculated from Gross Domestic Product / GDP (balance of shopping ability) per capita. To increase HDI, one component that can be done is to increase life expectancy after birth through improving healthy living behaviors. Improving healthy behavior can be done if health facilities that meet the standards and low-cost health care can be fulfilled. The reality in Indonesia is that most health facilities are inadequate and medical costs are very expensive. Indonesia does not yet have an integrated medical service system with a referral system.

As a result, health services in Indonesia have become extremely expensive and commercial. Indonesia only has a hospital legal system, it does not yet have a health care system law. Poor families in Indonesia are very vulnerable when it comes to health. Once a family member is seriously ill, it will have an impact on the family's welfare. Increasing HDI through health requires very expensive costs and impacts on other family expenses. Increasing health costs will reduce household consumption and ultimately reduce economic growth. 
ENTREPRENEURSHIP AND SUSTAINABILITY ISSUES

ISSN 2345-0282 (online) http://jssidoi.org/jesi/ 2020 Volume 8 Number 1 (September) http://doi.org/10.9770/jesi.2020.8.1(69)

Table 3. Short-term and Long-term Regression Results

\begin{tabular}{|c|c|c|c|c|}
\hline \multirow{2}{*}{ Variable } & \multicolumn{2}{|c|}{ Model 1} & \multicolumn{2}{|c|}{ Model 2} \\
\hline & Short- term & Long-term & Short- term & Long-term \\
\hline HDI & $-0.0042 * * *$ & -0.0073 & $-0.0024 * * *$ & -0.0040 \\
\hline LOG(CRT) & $0.2267 * * *$ & 0.3967 & $0.2779 * * *$ & 0.4663 \\
\hline LOG(CPEM) & $0.1213 * * *$ & 0.2122 & $0.1310 * * *$ & 0.2199 \\
\hline LOG(INDPENG) & $0.0430 * * *$ & 0.07523 & & \\
\hline LOG(JSPEND) & $0.1801 * *$ & 0.3151 & $0.1767 * * *$ & 0.2967 \\
\hline LOG(IMPOR) & & & 0.0036 & 0.0062 \\
\hline $\operatorname{LOG}(\operatorname{PDRB}(-1))$ & $0.4284 * * *$ & & $0.4040 * * *$ & \\
\hline $\mathrm{C}$ & $1.2333 * * *$ & & $1.1455 * * *$ & \\
\hline R-squared & 0.9999 & & 0.9999 & \\
\hline
\end{tabular}

Source: Author, 2019

Note:

$* * *$ significant at $\alpha 1 \% * *$ significant pada $\alpha 5 \% *$ significant pada $\alpha 10 \%$

Household consumption has an influence on economic growth, both in the short run and the long run. Increased consumption will encourage increased demand for goods and services and an increase in demand for goods and services will encourage increased production of goods. Increased demand will encourage increased investment and ultimately will drive economic growth. In model 1 (Table 3) the coefficient value of household consumption in the short term is 0.2267 meaning that an increase in household consumption by 1 percent will encourage economic growth in the short term by 0.2267 percent. Whereas in the long run, there is an increase in the coefficient value to 0.3967 , meaning that an increase in household consumption. In the long run, it will result in an increase in the economic growth of 0.3967 percent. Increasing the number of 0.2267 to 0.3967 can occur if household consumption can be produced in the region (import of goods can be reduced through the substitution strategy of imported goods) or the public is aware of buying domestic goods.

Government consumption has a positive effect in the short term as well as in the long term. Government Consumption Expenditures consist of the expenditure of civil servants, provision of public facilities, and subsidies. Provision of Public Facilities like government investment is to build new hospitals, build roads, build bridges and provide educational facilities, while retirement pensions are transferred payments. In model 1 the coefficient for government consumption in the short run is 0.1213 , meaning that any additional increase in government consumption of 1 percent will increase economic growth by 0.1213 percent in the short run. In the long run, a 1 percent increased in government consumption will increase by 0.2122 percent economic growth. Changes in increasing the coefficient in the short run to the long run from 0.1213 to 0.2122 indicate that local governments have succeeded in increasing the efficient use of the budget through budget efficiency from output to outcome. This efficiency improvement is shown in the short term to increase 1 percent of economic growth. An additional increase in government consumption expenditure is increased by 8.2 percent to only 4.7 percent (or a 4.5 percent budget savings).

The processing industry has an influence on economic growth both in the short and long term. Yogyakarta Special Region (DIY), as an area known as a city of education and culture, is believed to be a place for the rapid development of services and creative industries in it. The processing industry is one part of the investment that sustains the economy of the Special Region of Yogyakarta. Regression results show the coefficient value of the processing industry is 0.04 in the short term, which means that every 1 percent increase in the processing industry 


\section{ENTREPRENEURSHIP AND SUSTAINABILITY ISSUES}

ISSN 2345-0282 (online) http://jssidoi.org/jesi/

2020 Volume 8 Number 1 (September)

http://doi.org/10.9770/jesi.2020.8.1(69)

will increase DI Yogyakarta's economic growth by 0.04 percent in the short term. In the long run, the processing industry coefficient is 0.075 , which means that any increase in the manufacturing industry by 1 percent will drive economic growth by 0.075 percent. Although the manufacturing sector in Yogyakarta has an influence on economic growth, but its effect is very small compared to other sectors. This happens because of investments made by investors (both domestic and foreign investors) in traditional industries (Táncošová, 2019).

Educational services have a positive influence on economic growth both in the short and long term. Yogyakarta is famous as a city of education and culture. Yogyakarta in 2017 has 106 public and private universities. With a label as an educational city, it can absorb students from outside Yogyakarta. Increasing the number of students outside Yogyakarta causes the number of accommodations for students to increase and consumption to increase and will encourage economic growth. The coefficient value for education services is 0.18 meaning a 1 percent increase in education services will increase economic growth by 0.18 percent in the short term. In the short term, a 1 percent increase in economic growth requires an additional increase in education services by 5.5 percent. In the long run, a 1 percent increase in education services will increase economic growth by 0.31 percent. In the long term, a 1 percent increase in economic growth requires an additional 3.2 percent education services. Savings increase of 1 percent from 5.5 percent to 3.2 percent of education services due to Yogyakarta as one of the cities in Indonesia which has a low cost of living compared to other cities which are used as education cities. Thus, the high cost of education is offset by the low cost of living in the city of Yogyakarta.

Imports do not have an influence on economic growth in the Yogyakarta Region in both the long term and in the short term. This is because the raw materials used to produce products in the Yogyakarta Region can be fulfilled from within the Yogyakarta Region or from areas around. This study is in accordance with the results of research Ali, Ali \& Dalmar (2018). They state that imports does not have a significant effect on the GRDP.

\section{Conclusion}

HDI has a negating influence on economic growth. The increase in HDI actually inhibits economic growth because of the high cost of education and health. To overcome this, the government needs to do several solutions. First, people are required to have health insurance based on their ability to pay, so that people get intensive and efficient care in hospitals. With public health insurance, they are able to avoid additional financial burdens and access to better care. Second, there needs to be a collaboration between the world of education with companies both private and state-owned companies to be involved in education funding.

Household consumption has a role in driving economic growth, meaning that household consumption can encourage economic growth through increased demand for household consumption goods. If the demand for consumer goods cannot be fulfilled by the local industry, it will cause an increase in imports of household consumption goods. To overcome this problem, the government needs to implement some strategies. First, the government limits imports by increasing the income tax rate $(\mathrm{PPh})$, especially for imported goods, household consumption. Second, the government encourages the substitution of imported goods by increasing the attractiveness of domestic investment, so that investors are interested and willing, and invest their capital in Indonesia.

The second variable that has an influence on economic growth is government consumption. What is meant by government consumption is government expenditure for development, through education, health, and public facilities and the provision of subsidies. Even though it has an influence, the use of the budget for government expenditure has not been effective. This can be caused by the budget being used based on output and not the outcome. To overcome this, the government needs to make budget efficiency based on outcome performance.

The processing industry has an influence on economic growth, but the effect is very small. The Special Region of Yogyakarta is known as one of the provinces whose GRDP is supported by the industrial sector. However, as the 


\section{ENTREPRENEURSHIP AND SUSTAINABILITY ISSUES}

ISSN 2345-0282 (online) http://jssidoi.org/jesi/ 2020 Volume 8 Number 1 (September)

http://doi.org/10.9770/jesi.2020.8.1(69)

role of this industry is very small, the processing industry sector has not been able to provide welfare for the processing industry players. One strategy to overcome local governments must empower the local processing industry through cheap and affordable capital assistance, assistance in increasing human resources and government assistance in marketing products made by processing industries, as well as the campaign to love domestic products.

\section{Reference}

Abdul Karim, Z., Abdul Karim, B., \& Ahmad, R. (2010). Fixed investment, household consumption, and economic growth: a structural vector error correction model (SVECM) study of Malaysia. https://mpra.ub.uni-muenchen.de/27146/1/MPRA_paper_27146.pdf

Azeem Qureshi, M. (2009). Human development, public expenditure and economic growth: a system dynamics approach. International Journal of Social Economics, 36(1/2), 93-104. https://doi.org/10.1108/03068290910921217

Akanbi, B. E., Adagunodo, M., \& Satope, B. F. (2014). Climate change, human development and economic growth in Nigeria. International Journal of Humanities and Social Science, 4(13), 222-228.

Ali, A. A., Ali, A. Y. S., \& Dalmar, M. S. (2018). The impact of imports and exports performance on the economic growth of Somalia. International journal of economics and Finance, 10(1), 110-119.

Aslam, A. L. (2017). Does consumption expenditure induce the ecomonic growth? An empirical evidence from Sri Lanka. World Scientific News, 81(2), 221-234.

Bakari, S., \& Mabrouki, M. (2016). The Relationship among Exports, Imports and Economic Growth in Turkey.

Behun, M., Gavurova, B., Tkacova, A., \& Kotaskova, A. (2018). The impact of the manufacturing industry on the economic cycle of European Union countries. Journal of Competitiveness, 10(1), 23. https://doi.org/10.7441/joc.2018.01.02

Daniela-Mihaela, N. E. A. M. Ț. U., \& Oana-Georgiana, C. (2015). Correlations between human development and economic growth. Annals-Economy Series, 1, 118-122.

Elistia, E., \& Syahzuni, B. A. (2018). The Corelation on The Human Development Index (HDI) toward Economic Growth (GDP percapita) in 10 ASWAN Member Contries. Journal of Humanities and Social Studies, 1(2), 40-46. https://doi.org/10.33751/jhss.v2i2.949

Feriyantoa, N., \& El Aiyubbic, D. (2019). Regional spillover effect to Gross Regional Development Product (GRDP) in The Special Region of Yogyakarta, Indonesia. Entrepreneurship and Sustainability Issues, 6(3), 1318-1334. https://doi.org/10.9770/jesi.2019.6.3(19)

Gujarati, D. (2003). Basic Econometrics. Forth Edition. Singapura: McGraw-Hill.

Haraguchi, N., Cheng, C. F. C., \& Smeets, E. (2017). The Importance of manufacturing in Economic Development: Has this changed?. World Development, 93, 293-315. https://doi.org/10.1016/j.worlddev.2016.12.013

Hussain, M. A., \& Saaed, A. A. J. (2015). Impact of exports and imports on economic growth: Evidence from Tunisia. Journal of Emerging Trends in Economics and Management Sciences, 6(1), 13-21.

Iskandar, I. (2017). Effect of Human Development Index Fund on Economic Growth Through A Special Autonomy. Jurnal Ekonomi Pembangunan: Kajian Masalah Ekonomi dan Pembangunan, 18(1), 40-49. https://doi.org/10.23917/jep.v18i1.2920

Jahan, S. (2017). Human development report 2016-human development for everyone (No. id: 12021).

Kartikasari, D. (2017). The Effect of Export, Import and Investment to Economic Growth of Riau Islands Indonesia. International Journal of Economics and Financial Issues, 7(4), 663-667.

Kim, S., Lim, H., \& Park, D. (2007). Could imports be beneficial for economic growth? some evidence from republic of Korea (No. 103). ERD Working paper series. 


\section{ENTREPRENEURSHIP AND SUSTAINABILITY ISSUES}

ISSN 2345-0282 (online) http://jssidoi.org/jesi/ 2020 Volume 8 Number 1 (September) http://doi.org/10.9770/jesi.2020.8.1(69)

Lains, P. (2006). Growth in a protected environment: Portugal, 1850-1950. In Research in Economic History (pp. 119-160). Emerald Group Publishing Limited. https://doi.org/10.1016/S0363-3268(06)24004-7

Rafiy, M., Adam, P., Bachmid, G., \& Saenong, Z. (2018). An Analysis of the Effect of Consumption Spending and Investment on Indonesia's Economic Growth. Iranian Economic Review, 22(3), 753-766. https://doi.org/10.22059/ier.2018.66642

Ramli, A., \& Andriani, A. A. (2013). The Effects of Consumption, Private Investment, and Government Expenditures on Economic Growth in South Sulawesi, Indonesia. Journal of Economics and Sustainable Development, 4(14), 145-153.

Ranis, G., Stewart, F., \& Ramirez, A. (2000). Economic growth and human development. World development, 28(2), 197-219.

Shome, S., \& Tondon, S. (2010). Balancing human development with economic growth: a study of ASEAN 5. Annals of the University of Petroşani, Economics, 10(1), 335-348.

Statistik, B. P. (2017). Indeks Pembangunan Manusia 2016. Jakarta (ID): Badan Pusat Statistik.

Su, D., \& Yao, Y. (2017). Manufacturing as the key engine of economic growth for middle-income economies. Journal of the Asia Pacific Economy, 22(1), 47-70. https://doi.org/10.1080/13547860.2016.1261481

Suri, T., Boozer, M. A., Ranis, G., \& Stewart, F. (2011). Paths to success: The relationship between human development and economic growth. World Development, 39(4), 506-522.

Táncošová, J. (2019). The role of foreign direct investment in the economy of Slovakia. Entrepreneurship and Sustainability Issues, 6(4), 2127-2135. https://doi.org/10.9770/jesi.2019.6.4(40)

Todaro, M. P., \& Smith, S. C. (2003). Economic Development, eight edition. UK: Pearson Addison Wesley.

\section{Acknowledgements}

LP3M Universitas Muhmamadiyah Yogyakarta, Indonesia supported this research.

\section{NANO PRAWOTO}

ORCID ID: https://orcid.org/0000-0001-7895-8911

\section{AGUS TRI BASUKI}

ORCID ID: https://orcid.org/0000-0001-8882-9785

Make your research more visible, join the Twitter account of ENTREPRENEURSHIP AND SUSTAINABILITY ISSUES: @Entrepr69728810

Copyright (C) 2020 by author(s) and VsI Entrepreneurship and Sustainability Center

This work is licensed under the Creative Commons Attribution International License (CC BY).

http://creativecommons.org/licenses/by/4.0/

C. (i) Open Access 